\title{
Retraction: Effects of edible coating on minimally processed pomegranate fruits
}

(2017, vol. 21, iss. 4, pp. 197-200)

Öz Tülin Ayșe, Eker Tülin

Engineering Faculty, Department of Food Engineering, University of Osmaniye Korkut Ata, Osmaniye, Turkey

\begin{abstract}
Paper is retracted from the journal at the request of the author. The reason for the retraction of paper is autoplagiarism, that is, at the same time publishing similar paper in another journal.
\end{abstract}

Authors requested retraction of the paper by statement. 